\title{
Optimization Processing Parameters for Curcuma xanthorriza Oleoresin Yield and its Antioxidant Activity
}

\author{
Zarani M. Taher and Mohamad R. Sarmidi
}

Institute of Bioproducts Development (IBD), Universiti Teknologi Malaysia (UTM), Skudai, Johor, Malaysia

\begin{abstract}
Processing is a critical aspect of herbal based products, and processing method is known to affect the content, activity and bioavailability of bioactive compounds. Extraction of oleoresin from Curcuma xanthorriza is effected by several processing parameters. Appropriate solvent selection such as polar solvent result in better extraction yield while lower polarity solvent end up with extracts having higher concentration of active compounds. In this study, different processing parameters were carried out including blanching treatment (boiled, steamed) at range of time (24 hours, 48 hours and 72 hours), solvent of extraction (methanol, ethanol and acetone). The curcuminoid content and antioxidant activity were determined in Curcuma xanthorriza oleoresin. The result obtained was proved that ethanol was the most effective solvent. Blanching treatment affects the yield of oleoresin and promotes the release of curcuminoids content.
\end{abstract}

Keywords: Curcuma xanthorriza, optimisation, blanching, solvent, antioxidant activity.

\section{INTRODUCTION}

The emergence of functional food, dietary supplements which have medicinal benefits has become important for public health [1]. Herbs have been used throughout human history as source of food, medicines, beauty enhancer, and fragrances. Phytochemicals have evolved from herbalism and commonly used to define the biologically active molecules in plants however, vitamins or nutrients is not included.

Recently, there has been a considerable interest in finding natural antioxidants from plant materials to replace synthetic antioxidant in food products [26].Temulawak or Curcuma xanthorriza is a curcuma genus belongs to the great Zingberacea family used medicinally in Southeast Asia and also in any tropical regions. Most of the antioxidant compounds in a typical diet are derived from plant sources and belong to the various classes of compounds with a wide variety of physical and chemical properties. C. xanthorriza contains antioxidant properties of curcuminoids which is present in its oleoresin cells. The curcuminoids account for the yellow pigmentation in $C$. xanthorriza rhizome.

It is believed that biologically active phytochemicals and synergistic dynamics of all available chemical entities reported to have therapeutic effects to a plant or plant product [7-10]. Curcuminoids in C. xanthorriza consists of curcumin, $62 \%$ and desmethoxycurcumin

*Address correspondence to this author at the Institute of Bioproducts Development (IBD), 81310 Universiti Teknologi Malaysia (UTM), Skudai, Johor, Malaysia; Tel: +6(07) 5531573; Fax: +6(07) 5569706;

E-mail: mroji@ibd.utm.my
$38 \%$. As a results, C. xanthorriza exhibit strong yellow pigment colour than turmeric.

However, curcuminoids are found to exhibit antioxidant, anti-inflammatory, and anti-mutagenic properties and protects body from mutagens such as smoke and other pollutants [11]. These compositions make $C$. xanthorriza beneficial for health [12]. Other chemical composition in temulawak includes volatile oil, xanthorrizol, camphor, cinnamaldehyde, and starch [13]

Traditionally, C. xanthorriza rhizome has been used for medical purposes for hundreds of year by simple preparation. The $C$. xanthorriza rhizome was boiling in oil; some people dried the leaf or dried the rhizome to treat inflammation [14]. However, this conventional processing technique may degrade the compositional content and leading to affect the quality of phytochemical as functional food materials. Curcumin is poorly bioavailable and are facilitated via secondary metabolites [15]. Because of curcuminoids is known for its antioxidant properties therefore, to retain the antioxidant activity is vital. For wider industrial application, the need to retain the maximum antioxidants in processed food or plant extracts is crucial mainly for food and pharmaceutical industries. The objective of this paper is to study the effect of blanching and solvent extraction on the yield of $C$. xanthorriza oleoresin and its antioxidant activity. Thus, the understanding of the effects is useful in designing a better processing technology to retain antioxidants in C. xanthorriza oleoresin as antioxidant source other than for its conventional use for colour, flavour and aroma. 


\section{MATERIALS AND METHODS}

\subsection{Raw Material}

Fresh dried Curcuma xanthorriza rhizome was procured from Pagoh, Johor State, Malaysia. The first batch $(5.0 \mathrm{~kg})$ of temulawak rhizomes was procured for the preliminary phase experiments. All the chemicals and standard were purchased from Sigma Aldrich (USA) and of analytical grade.

\subsection{Extraction of Curcuma Xanthorriza}

Extraction of oleoresin was carried out by infusion method either with ethanol, acetone or methanol for 24 hours 48 hours and 72 hours. Pre-treatment was carried out prior extraction includes boiled for 1 hour or steamed for 15 mins, untreated (control). The oleoresin extracts were filtered and the solvents were removed, respectively. Each sample was then kept in an amber bottle at room temperature $\left(25^{\circ} \mathrm{C} \pm 2\right)$ for subsequent experiment.

\subsection{Yield of Oleoresin}

Yield of oleoresin was determined based on the initial mass of raw material

\subsection{Quantitative Analysis of Curcuminoids}

Curcumin content was determined by modified method [16] using spectrophotometer (Genesys10UV, Spectrosonic Unicam), with glass cuvettes (Sterna, Essex, UK) at $425 \mathrm{~nm}$ of wavelength. The determination of curcuminoids content was carried out using Thin Layer Chromatography (TLC) and qualitatively using dual UV detector wavelength 254/365 nm (Cole Parmer 9818 Series, Illinois).

The amount of curcumin [15] was calculated using Equation 1.0.

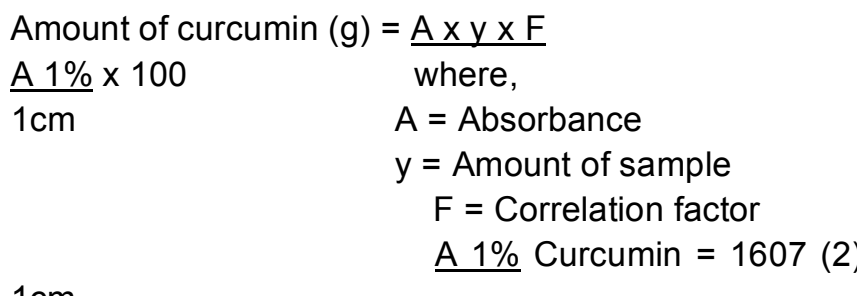

$1 \mathrm{~cm}$

\subsection{Antioxidant Activity}

A modified of the DPPH method [17] was used for the determination of antioxidant activity. A $1.5 \mathrm{ml}$ of DPPH solution (300 $\mu \mathrm{m}$ in $95 \%$ ethanol) was added to
$0.75 \mathrm{ml}$ oleoresin. After that, the mixture was shaken vigorously and left in the dark at room temperature for 20 minutes. $5 \mathrm{ml} \mathrm{BHT}$ was used as a standard. Finally, the absorbance at $517 \mathrm{~nm}$ was read from the spectrophotometer (Genesys10UV, Spectrosonic Unicam). The percentage (\%) radical scavenging activity was calculated as below.

Radical Scavenging activity $(\%)=$

Absorbance of control - Absorbance $\mathrm{t}=20 \mathrm{~min} \times 100$ Absorbance of control

\section{RESULTS AND DISCUSSION}

\subsection{Effect of Pre- Treatment}

The results shows that the amount of $C$. xanthorriza oleoresin obtained from the experiment vary according to the type of solvent use and extraction time. Figure 1 shows the comparative on the value of $C$. xanthorriza oleoresin obtained with different types of solvent use (acetone, ethanol and methanol) and at different duration of extraction process $(24,48$ and $72 \mathrm{hr}$ ), respectively. Based on the results, steamed samples exhibit higher yield of oleoresin which approximately $20.8 \%$. However, boiling sample resulted a lower yield of oleoresin $(15.8 \%)$ than untreated samples which was $16.6 \%$ yield of oleoresin. Hence, steamed blanching treatment enhances the to extraction of oleoresin. The highest yield of oleoresin was obtained at 24 hours of steamed blanching treatment. Steaming causes the break up the oleoresin cells in cell matrix and facilitates the rapid release of oleoresin containing curcuminoids. Therefore, more oleoresin was released into the surrounding area. The results indicate that blanching treatment was pronounced to increase the oleoresin containing curcuminoids. Despite increased the oleoresin; blanching treatment also potentially increased the superficial area available for mass transfer leading to increase the yield.

\subsection{Effect of Solvent on Extraction Yield}

Many factors contribute to the efficacy of the solvent extraction, such as the type of solvent, the $\mathrm{pH}$, the temperature, the number of steps, the liquid-to-solid ratio, and the particle size and shape of the plant matrix [18]. From the results in Figure 2 methanol give the highest yield followed by acetone and ethanol. The overall yield results indicate that methanol was more effective in extracting oleoresin from $C$. xanthorriza compared to acetone and ethanol. The maximum yield of oleoresin obtained was $41.8 \%(\mathrm{w} / \mathrm{w})$. The result 


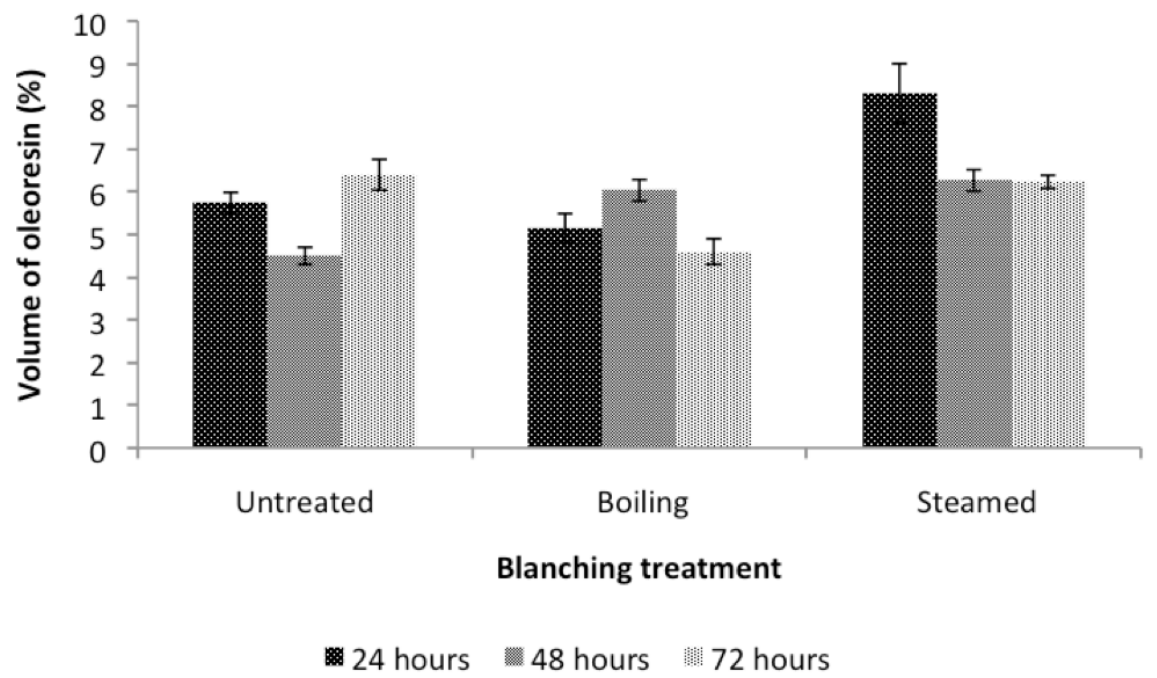

Figure 1: Yield of oleoresin (\%) using type of time and blanching treatments at different time.

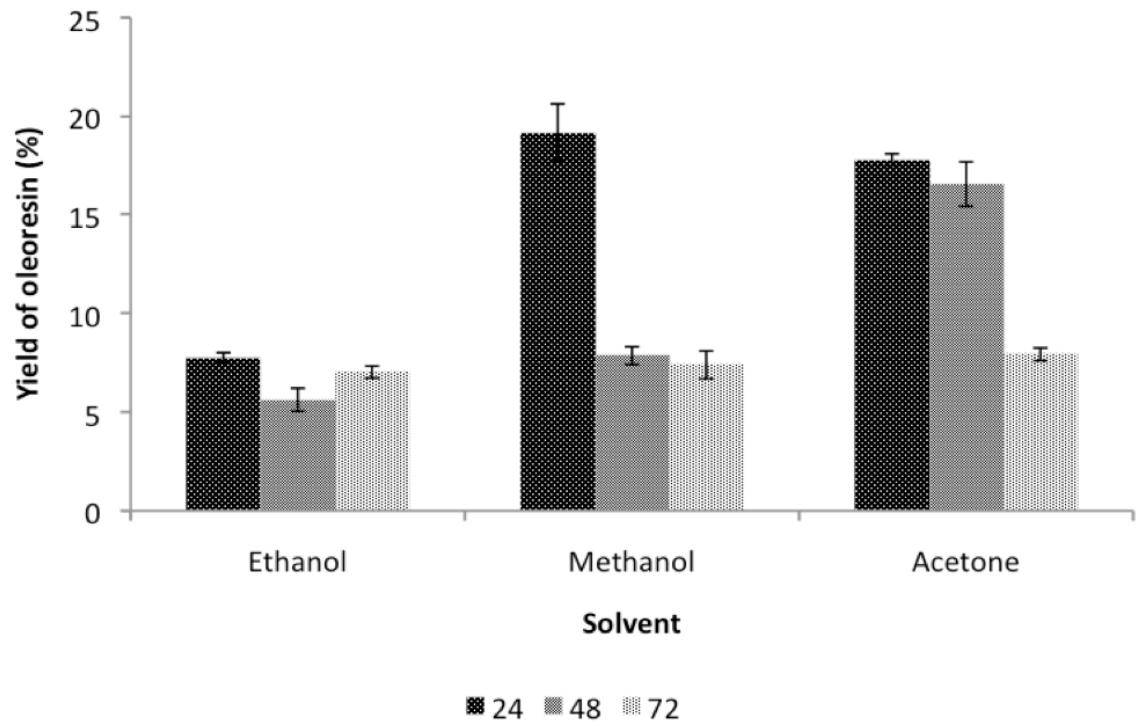

Figure 2: Yield of oleoresin using different solvent at different extraction time.

indicates that the suitable time for the extraction process is at 24 and 48 hours and under these conditions the value of oleoresin obtained was higher. Therefore, this suggests that there would be two different appropriate strategies of extraction. One is for extracting optimum antioxidant properties from the whole oleoresin and the other is for the optimum yield of oleoresin itself without consideration of antioxidant properties.

Addition of water to ethanol improved extraction rate [19] however, high water content may increase concomitant extraction of other compounds [20]. This suggesting that only different amount of antioxidant activity was obtained but not different compounds were recovered.
A chromatographic method for qualitative analysis was carried out in this work. Methanol gives higher $R_{f}$ values which is 0.7653 at 24 hours of extraction time, 0.6837 for ethanol at 48 hours and acetone 0.5155 for 24 hours. These results suggested that the blanching treatments studied did not qualitatively affect the presence of curcuminoids in the processed $C$. xanthorriza oleoresin. Therefore, blanching treatment preserve the antioxidant property.

\subsection{Curcuminoid Content in C. xanthorriza Oleoresin}

For quantitative analysis of curcumin content in C. xanthorriza oleoresin, the value was determined as $\%$ of curcumin content based on the standard curcumin calibration curve [21]. Curcuminoids are contained in 
Table 1: Curcuminoid Content in C. xanthorrhiza Oleoresin by Spectrophotometer Method

\begin{tabular}{|c|c|c|}
\hline Type of solvent & Extraction time & Curcuminoid content (\%) \\
\hline \hline \multirow{3}{*}{ Acetone } & 24 & $0.054 \pm 0.003$ \\
\cline { 2 - 3 } & 48 & $0.052 \pm 0.001$ \\
\cline { 2 - 3 } & 72 & $0.036 \pm 0.002$ \\
\hline \multirow{3}{*}{ Ethanol } & 24 & $0.034 \pm 0.002$ \\
\cline { 2 - 3 } & 48 & $0.069 \pm 0.005$ \\
\cline { 2 - 3 } & 72 & $0.100 \pm 0.003$ \\
\hline \multirow{3}{*}{ Methanol } & 24 & $0.012 \pm 0.001$ \\
\cline { 2 - 3 } & 48 & $0.011 \pm 0.002$ \\
\cline { 2 - 3 } & 72 & $0.008 \pm 0.002$ \\
\hline
\end{tabular}

the oleoresin cells [22]. The curcumin content in $C$. xanthorrhiza oleoresin by spectrophotometer method $[21,22]$ is display in Table 1 . Based on results, the minimum curcumin content $(0.007 \%)$ was extracted with methanol at 72 hours of extraction time. Extraction using ethanol as a solvent gives maximum curcumin content $(0.01 \%)$ at 72 hours of extraction time. The extraction using ethanol results in maximum curcumin content which is $0.20 \%$ while extract curcumin with methanol results in minimum curcumin content $(0.003$ $\%)$.

\subsection{Antioxidant Activity of Curcuminoids}

The antioxidants play an important role in protection against disorder cause by oxidant damage [23]. In this study, curcumin is the active compound that contributes to the antioxidant activity [24]. Higher $\mathrm{DPPH}$ radical scavenging value, which indicates higher antioxidant activity, was found for ethanol (18.31\%) and acetone ( $38.75 \%)$ extracts. These values also are higher than the antioxidant activity for butyl hydroxyl toluene (BHT). Acetone extract shows the strongest DPPH radical scavenging activity at $16.28 \%$. This proves that solvents with a polarity between acetone and ethanol are good in extracting curcumin content in C. xanthorriza extract. Curcumin is responsible for the antioxidant activity of $C$. xanthorriza extract. Further work need to be done for the up-scaling the extraction to obtain the curcuminoid content [25].

\section{CONCLUSION}

Based on the results obtained, retention of antioxidants during processing can be achieved best using fresh materials with ethanol as solvent for extraction. Blanching treatments increase the yield of oleoresin but decreases the antioxidant activity. The

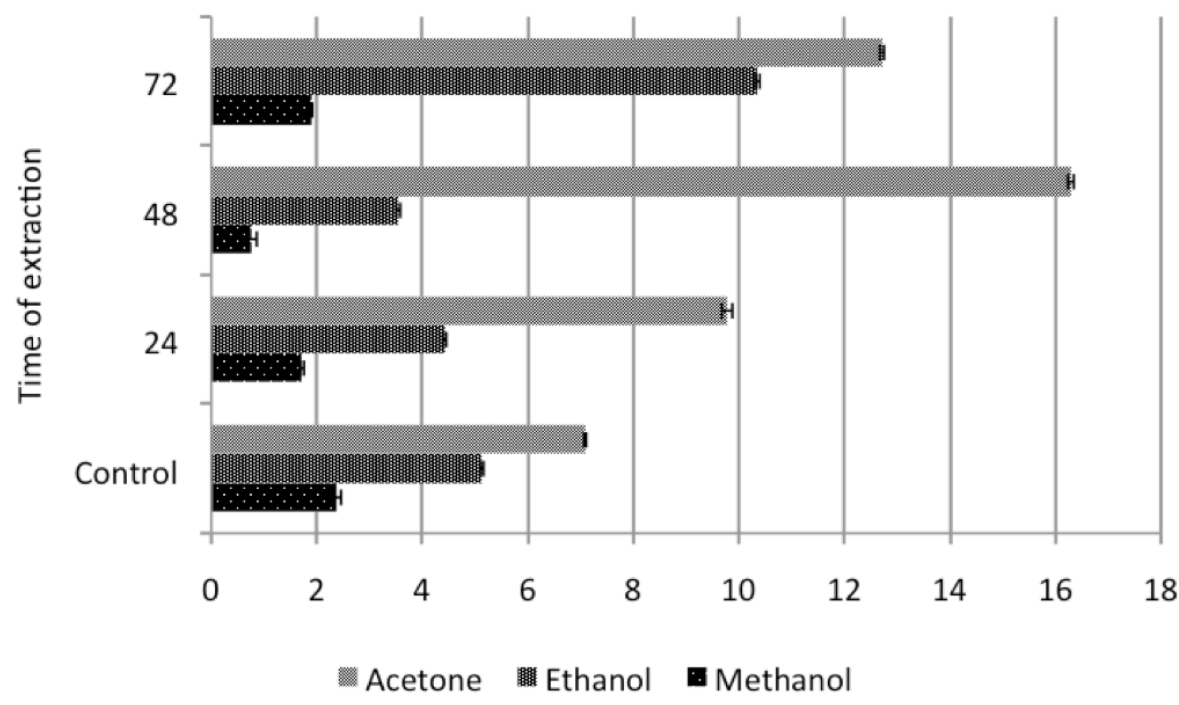

Figure 3: The comparison of antioxidant activity of $C$. xanthorriza oleoresin indicated by DPPH radical scavenging activity measured in inhibition percentage (IP) compared to synthetic antioxidants (BHT). 
results suggest that fresh material is preferred over blanched samples due to its convenience to use and a higher content of bioactive compounds as well as a higher antioxidant activity. This property can be highlighted as an additional advantage taking into account that ethanol unlike acetone or methanol is generally considered GRAS (Generally Recognized as Safe).

It is important to determine the effect of processing on bioactive compounds so that processing time and temperature can be optimized to keep functionality of the active compounds. Since longer extraction time would also result in higher yield and curcumin content, the most appropriate processing parameters for retention of antioxidant activity should be determined.

\section{ACKNOWLEDGEMENTS}

The authors would like to thank The Ministry of Science, Technology and Environment of Malaysia for financing the project, CEPP, UTM for laboratory facilities.

\section{REFERENCES}

[1] Zhao J, Ge LY, Xiong W, Leong F, Huang LQ, Li SP. Advanced development in phytochemicals analysis of medicine and food dual purposes plants used in China (2011-2014). J Chromatogr A 2015; S0021-9673(15)012716.

http://dx.doi.org/10.1016/j.chroma.2015.09.006

[2] Apati A, Szentmihalyi SK, Kristo T, Papp I, Vinkler P, Szoke E, Kery A. Herbal remedies of Solidago-correlation of phytochemical characteristic and antioxidative properties. J Pharmaceut Biomed Anal 2003; 32: 1045-53. http://dx.doi.org/10.1016/S0731-7085(03)00207-3

[3] Chanwitheesuk A, Teerawutgulrag A, Rakariyatham N. Screening of antioxidant activity and antioxidant compounds of some edible plants of Thailand. Food Chem 2005; 92: 491-7.

http://dx.doi.org/10.1016/j.foodchem.2004.07.035

[4] Grigonis D, Venskutonis PR, Sivik B, Sandahl M, Eskilsson CS. Comparison of different extraction techniques for isolation of antioxidants from sweet grass (Hierochloe odorata). J Supercrit Fluids 2005; 33: 223-33.

\section{http://dx.doi.org/10.1016/j.supflu.2004.08.006}

[5] Lapornik B, Prosek M, Wondra AG. Comparison of extracts prepared from plant by-products using different solvents and extraction time. J Food Eng 2004; 71: 214-22. http://dx.doi.org/10.1016/j.jfoodeng.2004.10.036

[6] Jayaprakasha GK, Jaganmohan LR, Sakariah KK. Antioxidant activities of curcumin, demethoxycurcumin and bisdemethoxycurcumin. Food Chem 2006; 98: 720-4. http://dx.doi.org/10.1016/j.foodchem.2005.06.037

[7] Dhami N, Mishra AD. Phytochemical variation: How to resolve the quality controversies of herbal medicinal products? J Herbal Med 2015; 5: 118-27. http://dx.doi.org/10.1016/j.hermed.2015.04.002

[8] Ulrich-Merzenich G, Panek D, Zeitler H, Wagner H, Vetter $\mathrm{H}$. New perspectives for synergy research with the omictechnologies. Phytomed 2009; 16: 495-508.

\section{http://dx.doi.org/10.1016/j.phymed.2009.04.001}

[9] Wagner $\mathrm{H}$. Synergy research: approaching a new generation of phytochemicals. Fitoterapia 2011; 82: 34-7.

http://dx.doi.org/10.1016/j.fitote.2010.11.016

[10] Yang Y, Zhang Z, Li S, Ye X, Li X, He K. Synergy effects of herb extracts: pharmacokinetics and pharmacodynamic basis. Fitoterapia 2014; 92: 133-47.

http://dx.doi.org/10.1016/j.fitote.2013.10.010

[11] Jayaprakasha GK, Jaganmohan LR, Sakariah KK. Chemistry and biological activities of $C$. longa. Trends in Food Sci Technol 2005; 16: 533-48.

http://dx.doi.org/10.1016/j.tifs.2005.08.006

[12] Batubara I, Julita I, Darusman LK, Muddathir AM, Mitsunaga T. Flower bracts of Temulawak (Curcuma xanthorrhiza) for skin care: anti-acne and whitening agents. Procedia Chemistry 2015; 14: 216-24. http://dx.doi.org/10.1016/j.proche.2015.03.031

[13] Musfiroh I, Muchtaridi M, Muhtadi A, Diantini A, Nur Hasanah A, Udin LZ, Yasmiwar S, Mustarichie R, Kartasasmita Rahmana E, Ibrahim S. Cytotoxicity studies of xanthorrhizol and its mechanism using molecular docking simulation and pharmacophore modelling. J Appl Pharm Sci 2013; 7-15. http://dx.doi.org/10.7324/JAPS.2013.3602

[14] Lantz RC, Chen GJ, Sarihan M, Solyom AM, Jolad SD, Timmermann BN. The effect of extracts from ginger rhizome on inflammatory mediator production. Phytomed 2007; 14: 123-8. http://dx.doi.org/10.1016/j.phymed.2006.03.003

[15] Lakhan SE, Ford CT, Tepper D. Zingiberaceae extracts for pain: a systematic review and meta-analysis. Nutrit J 2015; 14: 50.

http://dx.doi.org/10.1186/s12937-015-0038-8

[16] Eugster $\mathrm{CH}$. Chemical derivatization: microscale tests for the presence of common functional groups in carotenoids, in: G. Britton, S. Liaaen-Jensen, H. Pfander (Eds.), Carotenoids, Isolation and Analysis, vol. 1A, Birkhäuser Verlag, Basel, 1995; pp. 71-80.

[17] Yamaguchi T, Takamura H, Matoba T, Terao J. HPLC method for evaluation of the free radical-scavenging activity of foods by using 1, 1-diphenyl-2-picrylhydrazyl. Biosci Biotechnol Biochem 1998; 62(6): 1201-4. http://dx.doi.org/10.1271/bbb.62.1201

[18] Houghton PJ, Raman A. Laboratory handbook for the fractionation of Natural Extract. London: Chapman \& Hall 1998.

http://dx.doi.org/10.1007/978-1-4615-5809-5

[19] Spigno G, Tramelli L, De Faveri DM. Effects of extraction time, temperature and solvent on concentration and antioxidant activity of grape marc phenolics. J Food Eng 2007; 81: 200-8.

http://dx.doi.org/10.1016/j.jfoodeng.2006.10.021

[20] Harborne JB. Phytochemical Methods A guide to Modern Techniques of Plant Analysis. $3^{\text {rd. }}$ ed. London: Chapman and Hall 1998.

[21] Tomren MA, Masson M, Loftsson T, Tonnesen HH. Studies on curcumin and curcuminoids XXXI. Symmetric and asymmetric curcuminoids: stability, activity and complexation with cyclodextrin. Int J Pharmaceut 2007; 338: 27-38. http://dx.doi.org/10.1016/j.ijpharm.2007.01.013

[22] Tonnesen HH. Studies on Curcumin and Curcuminoids XVIII. Evaluation of Curcuma products by the use of standardized reference colour values. Z Lebensm Unters Forsch 1992; 194: 129-30. http://dx.doi.org/10.1007/BF01190182

[23] Pokorny J, Schmindt S. Natural Antioxidant Functionality during Food Processing. In Pokorny, J., Yanishlieva, N. and Gordon, M. (Ed.). Antioxidants in Food. Practical Application. Cambridge: Woodhead Publishing Limited 2001; 331-51. http://dx.doi.org/10.1533/9781855736160.4.331 
[24] Tonnesen $\mathrm{HH}$, Karlsen J. High performance liquid chromatography of curcumin and related compounds. J Chromatogr 1993; 259: 367-71. http://dx.doi.org/10.1016/S0021-9673(01)88022-5
[25] Tiwari KK. Extraction Technologies Related To Food Processing. In Gaonkar AG, Ed. Food Processing: Recent Developments. Amsterdam: Elsevier Science 1995; 269-301. http://dx.doi.org/10.1016/B978-044481500-2/50016-5

Received on 20-09-2015

DOI: http://dx.doi.org/10.6000/1927-3037.2015.04.03.3

(C) 2015 Taher and Sarmidi; Licensee Lifescience Global.

This is an open access article licensed under the terms of the Creative Commons Attribution Non-Commercial License (http://creativecommons.org/licenses/by-nc/3.0/) which permits unrestricted, non-commercial use, distribution and reproduction in any medium, provided the work is properly cited. 